\title{
Abomasal or ruminal administration of flax oil and hulls on milk production, digestibility, and milk fatty acid profile of dairy cows
}

\author{
R. Kazama, ${ }^{*}$ C. Côrtes,† D. da Silva-Kazama, ${ }^{*}$ N. Gagnon,† C. Benchaar,† L. M. Zeoula, ${ }^{*}$ \\ G. T. D. Santos, ${ }^{*}$ and H. V. Petit $\dagger^{1}$ \\ *Departamento de Zootecnia, Universidade Estadual de Maringa, 87020-900 Maringa, PR, Brazil \\ †Dairy and Swine Research and Development Centre, Agriculture and Agri-Food Canada, Stn Lennoxville, Sherbrooke, QC J1M 1Z3, Canada
}

\begin{abstract}
Four ruminally fistulated primiparous lactating Holstein cows were assigned to a $4 \times 4$ Latin square design to determine the effects of the site of administration (rumen or abomasum) of flax oil and flax hulls on diet digestibility and milk fatty acid profile of dairy cows. The treatments were 1) oil and hulls administered in the rumen and abomasal infusion of water (RUM/RUM), 2) oil and hulls infused in the abomasum (ABO/ABO), 3) oil administered in the rumen and hulls infused in the abomasum (RUM/ABO), and 4) oil infused in the abomasum and hulls placed in the rumen $(\mathrm{ABO} /$ RUM). Cows on the ABO/ABO and RUM/RUM treatments had the highest and lowest amounts of basal dry matter eaten, respectively. Higher dry matter digestibility was obtained when flax oil bypassed the rumen $(\mathrm{ABO} / \mathrm{ABO}$ and $\mathrm{ABO} / \mathrm{RUM})$ compared with when flax oil was administered directly in the rumen (RUM/ $\mathrm{ABO}$ and RUM/RUM). Apparent digestibility of ether extract was higher when flax hulls were administered in the rumen (RUM/RUM and ABO/RUM) compared with when flax hulls were infused in the abomasum ( $\mathrm{ABO} / \mathrm{ABO}$ and $\mathrm{RUM} / \mathrm{ABO}$ ). The lowest digestibility of acid detergent fiber and neutral detergent fiber was obtained when both flax products were added in the rumen, which may be attributed to the high amount of oil present in the rumen $(7.8 \%$ of total dry matter input). The lowest yield of $4 \%$ fat-corrected milk was obtained for cows on the RUM/RUM treatment, probably as a result of lower dry matter intake and digestibility of fiber. Milk concentrations of protein, fat, total solids, and lactose were similar among treatments. Administration of oil and hulls in the rumen resulted in the highest concentrations of intermediate products of biohydrogenation and total trans fatty acids in milk fat compared with the other treatments. All ratios of $n-6$ to n-3 fatty acids in milk fat were lower than the 4 to
\end{abstract}

Received March 2, 2010

Accepted June 25, 2010.

${ }^{1}$ Corresponding author: helene.petit@agr.gc.ca
1 ratio recommended to improve human health. These results suggest that the presence of both flax oil and flax hulls in the rumen decreases $4 \%$ fat-corrected milk yield and digestibility but provides a desirable fatty acid profile of milk to enhance consumers' health.

Key words: dairy cow, milk fat, n-3 fatty acid, flax

\section{INTRODUCTION}

Research has demonstrated several health benefits of n-3 fatty acids (FA) to humans, including the prevention of cardiovascular diseases and breast and prostate cancers and improvement in visual acuity (Simopoulos, 1996; Wright et al., 1998). Flaxseed, which is rich in n-3 linolenic acid ( cis-18:3; LNA), has been shown to decrease proportions of short-chain FA (SCFA) and medium-chain FA and increase those of long-chain FA in milk fat of dairy cows (Mustafa et al., 2003; Petit, 2003). However, the increase in proportion of LNA in milk fat is generally modest because of extensive biohydrogenation of polyunsaturated FA by ruminal bacteria (Doreau et al., 2009). Nevertheless, the proportion of LNA in milk fat increased to $13.9 \%$ of total FA when cows were infused with $500 \mathrm{~g} / \mathrm{d}$ of flax oil in the abomasum and DMI was not affected by oil infusion (Petit et al., 2002). In contrast, abomasal infusion of $400 \mathrm{~g} / \mathrm{d}$ of vegetable oil containing $41.6 \% 18: 1$ and $44.1 \%$ 18:2 has been shown to reduce DMI of dairy cows (Benson et al., 2001). Whether the negative effect of polyunsaturated FA on feed intake is attributable to specific long-chain FA present in the small intestine or other parts of the gastrointestinal tract has not been determined accurately (Drackley et al., 2007).

Flax hull is a co-product obtained from flax processing that contains $24 \% \mathrm{CP}$ and $30 \%$ ether extract in the DM (Gagnon et al., 2009) and 53\% of total FA as LNA (Petit et al., 2009), which makes it a feed ingredient of interest for the diet of dairy cows. Flax hull supplementation tended to decrease the $\mathrm{pH}$ in ruminal fluid of cows (Gagnon et al., 2009), which may contribute to alter the extent, or pathways, or both, of ruminal biohydrogenation of dietary unsaturated FA. Indeed, 
Fuentes et al. (2009) showed lower ruminal pH to increase proportions of LNA in the effluent of dual-flow continuous culture fermenters with high concentrate to forage ratio. Moreover, isomerization of cis-18:2 (linoleic acid) to conjugated linoleic acid was strongly inhibited by a low ruminal $\mathrm{pH}$ and by increasing concentrations of LNA in the incubation media (Troegeler-Meynadier et al., 2003). Therefore, flax hull supplementation may contribute to modify milk FA profile. However, no information is available on flax hull supplementation for milk production. Previous results have shown that when flax hulls were placed in the rumen compared with the abomasum, the acetate to propionate ratio in the rumen decreased (Gagnon et al., 2009), which may result in decreased milk fat percentage. Therefore, the objectives of the present study were to investigate the effect of the site of administration (rumen and abomasum) of flax oil and flax hulls on diet digestibility and to evaluate whether ruminal bypass is required for one of these 2 feed ingredients for desirable milk FA profile and productivity of dairy cows.

\section{MATERIALS AND METHODS}

\section{Animals and Treatments}

Four primiparous lactating Holstein cows fitted with ruminal cannulas $(10 \mathrm{~cm}$; Bar Diamond Inc., Parma, ID) were used in a $4 \times 4$ Latin square design with 4 treatments and four 21-d periods balanced for residual effect. At the start of the experiment, the cows averaged $92 \pm 12$ DIM, $27.4 \pm 4.8 \mathrm{~kg}$ of milk/d, $561 \pm 10 \mathrm{~kg}$ of $\mathrm{BW}$, and $3.00 \pm 0.15 \mathrm{BCS}$ (5-point scale; Edmonson et al., 1989). The cows were kept in individual stalls and had free access to water. Cows were milked twice daily at 0830 and $2000 \mathrm{~h}$. All cows were fed the same TMR for ad libitum intake (10\% refusals on as fed basis) twice daily (0830 and $1430 \mathrm{~h}$ ). The diet (Table 1$)$ was formulated to meet requirements for cows that were 575 $\mathrm{kg}$ of BW and producing $30 \mathrm{~kg} / \mathrm{d}$ of milk with $3.8 \%$ fat (NRC, 2001). The experimental protocol complied with CCAC (1993) guidelines and was approved by the local animal care committee.

The 4 experimental treatments were 1) $0.4 \mathrm{~kg}$ of oil and $1.8 \mathrm{~kg}$ of hulls administered in the rumen and abomasal infusion of $20.0 \mathrm{~kg}$ of tap water (RUM/RUM); 2) $0.4 \mathrm{~kg}$ of oil, $1.8 \mathrm{~kg}$ of hulls, and $18.2 \mathrm{~kg}$ of tap water infused in the abomasum (ABO/ABO); 3) $0.4 \mathrm{~kg}$ of oil administered in the rumen and $1.8 \mathrm{~kg}$ of hulls and $18.2 \mathrm{~kg}$ of tap water infused in the abomasum (RUM/ ABO); and 4) $0.4 \mathrm{~kg}$ of oil and $20.0 \mathrm{~kg}$ of tap water infused in the abomasum and $1.8 \mathrm{~kg}$ of hulls administered in the rumen $(\mathbf{A B O} / \mathbf{R U M})$. For the $\mathrm{ABO} /$
RUM treatment, 2 different infusion lines were used to pump oil and water, each at a constant flow rate, in a larger line using a Y-shape connection line leading to the abomasum. Abomasal infusions consisted of $20 \mathrm{~kg} / \mathrm{d}$ of solution (water or water + hulls). During the first $7 \mathrm{~d}$ of each 21 -d period, only $30 \%$ of the experimental dose of oil and hulls was administered in the abomasum over a 7 -h period. From d 8 to 21, infusion in the abomasum was conducted with $100 \%$ of the experimental dose of oil and hulls over a 23-h period. Administration in the rumen was done by adding one-third each of oil and hulls 3 times daily (0930, 1430, and $2130 \mathrm{~h}$ ) during all the experiments. All details on preparation of infusates of flax products were described by Gagnon et al. (2009).

Flax hull is a commercially available product (Natunola Health Inc., Nepean, Ontario, Canada). About $44 \%$ of the lipids were provided by flax oil and $56 \%$ by flax hulls for a total amount of $900 \mathrm{~g}$ daily, thus resulting in a fat intake below 6 to $7 \%$ of the DM, which is known to have little effect on DMI (NRC, 2001). Fatty acid profiles of flax oil and hulls are shown in Table 1.

\section{Sampling}

Samples of the diet and flax hulls were taken daily from d 14 to 21 and pooled by period. All samples were frozen at $-20^{\circ} \mathrm{C}$ for subsequent drying at $55^{\circ} \mathrm{C}$. To predict fecal output and digestibility, a capsule of chromic oxide $\left(\mathrm{Cr}_{2} \mathrm{O}_{3}\right)$ was inserted in the rumen once daily at $0900 \mathrm{~h}$ from d 11 to 20, supplying a total of $10 \mathrm{~g}$ of $\mathrm{Cr}_{2} \mathrm{O}_{3} / \mathrm{d}$. Fecal grab samples $(100 \mathrm{~g})$ were taken twice daily at 0830 and $1630 \mathrm{~h}$ and accumulated from d 15 to 19 . Fecal samples were dried at $55^{\circ} \mathrm{C}$ for $48 \mathrm{~h}$ and composited by cow within period for further chemical analysis. Fecal and TMR samples were ground through a 1-mm screen in a Wiley mill and afterward were composited by cow within period for further analysis. From d 22 to 28 , milk samples were taken from each cow for 14 consecutive milkings and pooled on a yield basis to obtain 1 milk sample per cow within period. One sample was kept frozen at $-20^{\circ} \mathrm{C}$ without preservative for further analyses of milk fat and $\mathrm{FA}$ profile. Another sample was stored at $+4^{\circ} \mathrm{C}$ with a preservative (bronopol-B2) until analysis for protein, urea N, lactose, and TS.

\section{Chemical Analysis}

Dry matter of feed ingredients and diets was determined in a forced-air oven according to AOAC (1990) procedure 934.01. Concentration of total $\mathrm{N}$ in milk, TMR, and feces was determined by thermal conduc- 
Table 1. Ingredient, chemical composition, and fatty acid profile of the total mixed diet, flax hulls, and flax oil

\begin{tabular}{|c|c|c|c|}
\hline Item & $\begin{array}{c}\text { Total } \\
\text { mixed diet }\end{array}$ & $\begin{array}{l}\text { Flax } \\
\text { hulls }\end{array}$ & $\begin{array}{c}\text { Flax } \\
\text { oil }\end{array}$ \\
\hline \multicolumn{4}{|l|}{ Ingredient, $\%$ of DM } \\
\hline Grass silage & 32.0 & & \\
\hline Corn silage & 32.2 & & \\
\hline Cracked corn grain & 11.9 & & \\
\hline Ground barley & 7.7 & & \\
\hline Soybean meal & 10.2 & & \\
\hline Top supplement ${ }^{1}$ & 2.8 & & \\
\hline Mineral $^{2}$ & 2.5 & & \\
\hline Ca carbonate & 0.7 & & \\
\hline \multicolumn{4}{|l|}{ Chemical analysis $^{3}$} \\
\hline DM, \% & 41.8 & 93.2 & \\
\hline $\mathrm{CP}, \%$ of $\mathrm{DM}$ & 16.0 & 23.5 & \\
\hline Ether extract, $\%$ of DM & 2.3 & 29.4 & \\
\hline $\mathrm{NDF}, \%$ of DM & 29.7 & 19.4 & \\
\hline $\mathrm{ADF}, \%$ of $\mathrm{DM}$ & 20.4 & 14.3 & \\
\hline $\mathrm{NE}_{\mathrm{L}}, \mathrm{Mcal} / \mathrm{kg}$ of DM & 1.58 & 1.65 & \\
\hline \multicolumn{4}{|c|}{ Fatty acid ${ }^{4} \mathrm{~g} / 100 \mathrm{~g}$ of total fatty acid methyl esters } \\
\hline $12: 0$ & 0.71 & $\mathrm{ND}^{5}$ & ND \\
\hline cis-11 12:1 & 0.54 & ND & ND \\
\hline $14: 0$ & 0.63 & 0.66 & 0.41 \\
\hline $15: 0$ & 0.22 & ND & ND \\
\hline $16: 0$ & 16.56 & 6.90 & 5.33 \\
\hline cis-9 16:1 & 0.33 & 0.43 & 0.39 \\
\hline $17: 0$ & 0.18 & ND & ND \\
\hline $18: 0$ & 1.89 & 2.36 & 3.90 \\
\hline cis-9 18:1 & 17.12 & 18.10 & 18.80 \\
\hline cis-11 18:1 & 1.08 & 1.07 & 0.84 \\
\hline cis-9, cis 12 18:2 & 46.02 & 17.2 & 16.1 \\
\hline cis-6, cis- 9, cis-12 18:3 & 0.08 & ND & ND \\
\hline cis-9, cis-12, cis-15 $18: 3$ & 13.19 & 52.90 & 53.70 \\
\hline $20: 0$ & 0.22 & ND & ND \\
\hline cis-11 20:1 & 0.59 & ND & ND \\
\hline cis-11, cis-14 20:2 & 0.08 & ND & ND \\
\hline $22: 0$ & 0.20 & 0.09 & 0.34 \\
\hline $24: 0$ & 0.33 & 0.29 & 0.19 \\
\hline
\end{tabular}

${ }^{1}$ Contained $20 \%$ canola meal, $30 \%$ corn gluten meal, $20 \%$ soybean meal, and $30 \%$ brewer's corn.

${ }^{2}$ Contained $9.02 \% \mathrm{Ca}, 4.90 \% \mathrm{P}, 4.89 \% \mathrm{Mg}, 1.76 \% \mathrm{~S}, 14 \% \mathrm{Na}, 1.43 \% \mathrm{~K}, 2,068 \mathrm{mg} / \mathrm{kg}$ of Fe, $2,718 \mathrm{mg} / \mathrm{kg}$ of $\mathrm{Zn}$, $447 \mathrm{mg} / \mathrm{kg}$ of Cu, $1,814 \mathrm{mg}$ of $\mathrm{Mn}, 69 \mathrm{mg} / \mathrm{kg}$ of I, $7 \mathrm{mg} / \mathrm{kg}$ of Co, $20 \mathrm{mg} / \mathrm{kg}$ of Se, $452,000 \mathrm{IU} / \mathrm{kg}$ of vitamin A, $58,000 \mathrm{IU} / \mathrm{kg}$ of vitamin $\mathrm{D}_{3}$, and $2,692 \mathrm{IU} / \mathrm{kg}$ of vitamin $\mathrm{E}$.

${ }^{3}$ Mean of 4 pool samples prepared by compositing 8 daily samples collected from d 14 to 21 .

${ }^{4}$ Mean of 1 sample obtained from 4 pool samples prepared by compositing 8 daily samples from d 14 to 21 .

${ }^{5} \mathrm{ND}=$ not detected

tivity (Leco FP-428 Nitrogen Determinator, Leco, St. Joseph, MI). The concentration of NDF in TMR and feces was determined as described by Van Soest et al. (1991) without the use of sodium sulfite and with the inclusion of heat-stable $\alpha$-amylase. The ADF content in TMR and feces was determined according to AOAC (1990) method 973.18. The NDF and ADF procedures were adapted for use in an Ankom ${ }^{200}$ Fiber Analyzer (Ankom Technology Corp., Fairport, NY). Concentration of ether extract in diets and feces was determined according to AOAC (1990) method no. 7.060 with Tecnal TE-044/1 (Piracicaba, São Paulo, Brazil). Lactose, $\mathrm{TS}$, and urea $\mathrm{N}$ concentrations in milk samples were analyzed by infrared spectrophotometer (System 4000 MilkoScan, Foss Electric, Hillerød, Denmark). Milk fat concentration was determined by the method of RoeseGoettlib (AOAC, 1990).

Milk fat was extracted and FA were methylated according to the methods described by Chouinard et al. (1997), and in situ transesterification was performed on diets according to Park and Goins (1994). The amount of FA in diets and flax hulls was not quantified because no internal standard was used (Park and Goins, 1994). Individual FA were identified by comparison of gas chromatography peaks with peaks of known standards (GLC-463, Nu-Chek Prep Inc., Elysian, MN) on the basis of their retention times. The surface to concentration ratio for all identified FA was used to determine their respective concentrations. Agilent Chemstation Rev. B.01.03(204) software (Agilent Ltd., Mississauga, 
Ontario, Canada) was used for chromatogram integration and analysis. Each FA was expressed as weight percentage of total identified FA. Individual conjugated linoleic acid standards were used to identify trans-10, cis-12 18:2 (MT1254, Matreya LLC, Pleasant Gap, PA) and cis-9, trans-11 18:2 (\#MT1255, Matreya LLC). Fatty acid methyl esters were separated on an Agilent 6890 GLC fitted with an Agilent autosampler (model 7683, Agilent injector, Agilent Ltd.) and a flame ionization detector. Samples were introduced onto a 100-m Varian CP Sil 88 column (part number CP7489, Varian, Toronto, Ontario, Canada) via $1-\mu \mathrm{L}$ split injections with a split ratio of $75: 1$. The temperature program was as follows: level $1,72^{\circ} \mathrm{C}$ held for $0.5 \mathrm{~min}$; level 2 , 72 to $196^{\circ} \mathrm{C}$ at $2.4^{\circ} \mathrm{C} / \mathrm{min}$ increments, then held for 1 min; level 3,196 to $215^{\circ} \mathrm{C}$ at $1.7^{\circ} \mathrm{C} / \mathrm{min}$ increments, then held for $32 \mathrm{~min}$. Injector temperature was set at $230^{\circ} \mathrm{C}$ and the detector was set at $235^{\circ} \mathrm{C}$. Column head pressure was set at $206.8 \mathrm{kPa}$. A split injection liner (4 mm i.d.; Mandel, Guelph, Ontario, Canada) was used for all injections. Gas flow rates were as follows: helium (carrier), $1.0 \mathrm{~mL} / \mathrm{min}$; helium (make up), $34.5 \mathrm{~mL} /$ min; compressed air, $450 \mathrm{~mL} / \mathrm{min}$; and hydrogen, 40 $\mathrm{mL} / \mathrm{min}$.

Individual FA in diets were identified as described above for milk but with some modifications of the temperature program as follows: level $1,80^{\circ} \mathrm{C}$ held for 1.0 min; level 2,80 to $215^{\circ} \mathrm{C}$ at $1.55^{\circ} \mathrm{C} / \mathrm{min}$ increments, then held for $12 \mathrm{~min}$. Injector temperature was set at $230^{\circ} \mathrm{C}$ and the detector was set at $300^{\circ} \mathrm{C}$. Column head pressure was set at $124.3 \mathrm{kPa}$. A split injection liner (4 mm i.d.; Mandel) was used for all injections. Gas flow rates were as follows: hydrogen (carrier), $1.0 \mathrm{~mL} / \mathrm{min}$; nitrogen (make up), $44 \mathrm{~mL} / \mathrm{min}$; compressed air, 450 $\mathrm{mL} / \mathrm{min}$; and hydrogen, $40 \mathrm{~mL} / \mathrm{min}$.

\section{Statistical Analysis}

All data were analyzed using the MIXED procedure of SAS (SAS Institute, 2000) according to the model

$$
\mathrm{Y}_{\mathrm{ijk}}=\mu+\mathrm{a}_{\mathrm{i}}+\beta_{\mathrm{j}}+\tau_{\mathrm{k}}+\mathrm{e}_{\mathrm{ijk}},
$$

where $Y_{\mathrm{ijk}}=$ response variable, $\mu=$ overall mean, $\mathrm{a}_{\mathrm{i}}$ $=$ random effect of cow $\mathrm{i}, \beta_{\mathrm{j}}=$ effect of period $\mathrm{j}, \tau_{\mathrm{k}}$ $=$ effect of treatment $\mathrm{k}$, and $\mathrm{e}_{\mathrm{ijk}}=$ residual error. The residual effect of period was initially included in the model but was removed because it was not significant. Significance was declared at $P \leq 0.05$ and a trend at $0.05<P \leq 0.10$, unless otherwise stated. When a significant $F$-test was detected, multiple comparisons were done using Tukey's adjustment for the probability (Steel and Torrie, 1980).

\section{RESULTS AND DISCUSSION}

\section{Feed Intake and Diet Apparent Digestibility}

Dry matter intake of the basal diet and total DM input (basal diet + flax products administered in the rumen or infused in the abomasum) were affected by the site of supplementation of flax products (Table 2). Cows on the $\mathrm{ABO} / \mathrm{ABO}$ and RUM/RUM treatments had the highest and lowest amounts of basal DM eaten, respectively. Moreover, cows on the $\mathrm{ABO} / \mathrm{ABO}$ and RUM/ABO treatments had higher total DM input than those on the RUM/RUM and ABO/RUM treatments. The decrease in total DM input when adding flax products directly in the rumen compared with when they were administered in the abomasum may be related to the amount of fat delivered in the rumen, which averaged $0,2.3,5.8$, and $3.2 \%$ of total $\mathrm{DM}$ input for $\mathrm{ABO} / \mathrm{ABO}, \mathrm{RUM} / \mathrm{ABO}, \mathrm{RUM} / \mathrm{RUM}$, and $\mathrm{ABO} / \mathrm{RUM}$ treatments, respectively. This agrees with the results of Martin et al. (2008), who reported a depression in DMI when lactating dairy cows fed a corn silage-based diet were supplemented with $5.8 \%$ flax oil. According to Ikwuegbu and Sutton (1982), the size of depression in DMI is related to the amount of free flax oil included in the diet. Lower DMI with flax oil supplementation generally results from disturbances in ruminal function. The glycerol released from hydrolysis of polyunsaturated FA in the rumen is fermented mainly to propionate acid, which stimulates receptors located in the rumen wall and limits DMI (Allen, 2000; Forbes, 2000). Previous results (Gagnon et al., 2009) showed that the acetate to propionate ratio in the rumen of cows on the RUM/RUM treatment was lower than that of cows on the $\mathrm{ABO} / \mathrm{ABO}$ treatment, which could contribute to diminish DMI as a result of greater availability of propionate in the rumen.

In the present experiment, it was possible to compare the effect of supplementation of unprotected (by placing oil directly in the rumen) and protected (by abomasal infusion) flax oil. Higher digestibility of DM (Table 2) was obtained when flax oil bypassed the rumen through infusion in the abomasum $(\mathrm{ABO} / \mathrm{ABO}$ and $\mathrm{ABO} / \mathrm{RUM}$ treatments) compared with when flax oil was administered directly in the rumen (RUM/ABO and RUM/RUM treatments), indicating that flax oil has negative effects on ruminal digestibility of DM. Similarly, Sutton et al. (1983) reported a significantly lower rumen OM digestibility when sheep were fed diets containing $6.7 \%$ free oils from flax or coconut in the DM compared with those fed a diet with no added fat or diets with protected forms of flax oil or coconut oils. On the other hand, Ueda et al. (2003) did not observe any difference in ruminal digestibility of DM 
Table 2. Dry matter intake, digestibility, and amount of flax hulls and flax oil administered in the rumen, or infused in the abomasum, or both, of Holstein cows ${ }^{1}$

\begin{tabular}{lcccccc}
\hline & \multicolumn{5}{c}{ Treatment } & \\
\cline { 2 - 5 } Item & ABO/ABO & RUM/ABO & RUM/RUM & ABO/RUM & SE & $P$-value \\
\hline Basal DMI, ${ }^{2} \mathrm{~kg} / \mathrm{d}$ & $16.3^{\mathrm{a}}$ & $15.4^{\mathrm{ab}}$ & $13.3^{\mathrm{c}}$ & $13.8^{\mathrm{bc}}$ & 0.70 & 0.002 \\
Total DM input, ${ }^{3} \mathrm{~kg} / \mathrm{d}$ & $18.5^{\mathrm{a}}$ & $17.5^{\mathrm{a}}$ & $15.4^{\mathrm{b}}$ & $15.7^{\mathrm{b}}$ & 0.71 & 0.02 \\
Basal DMI, \% of BW & $2.78^{\mathrm{a}}$ & $2.60^{\mathrm{ab}}$ & $2.32^{\mathrm{c}}$ & $2.42^{\mathrm{bc}}$ & 0.09 & 0.002 \\
Total DM input, \% of BW & $3.16^{\mathrm{a}}$ & $2.97^{\mathrm{ab}}$ & $2.69^{\mathrm{c}}$ & $2.78^{\mathrm{bc}}$ & 0.09 & 0.002 \\
Digestibility, \% & & & & & & \\
DM & $73.0^{\mathrm{a}}$ & $70.5^{\mathrm{b}}$ & $70.3^{\mathrm{b}}$ & $73.4^{\mathrm{a}}$ & 1.80 & 0.01 \\
CP & $72.6^{\mathrm{ab}}$ & $70.0^{\mathrm{b}}$ & $73.6^{\mathrm{a}}$ & $73.5^{\mathrm{a}}$ & 1.60 & 0.03 \\
Ether extract & $89.4^{\mathrm{b}}$ & $87.9^{\mathrm{b}}$ & $92.7^{\mathrm{a}}$ & $93.2^{\mathrm{a}}$ & 0.92 & 0.003 \\
ADF & $62.8^{\mathrm{a}}$ & $61.9^{\mathrm{a}}$ & $54.2^{\mathrm{b}}$ & $62.8^{\mathrm{a}}$ & 2.8 & 0.01 \\
NDF & $62.3^{\mathrm{a}}$ & $59.6^{\mathrm{a}}$ & $53.0^{\mathrm{b}}$ & $60.3^{\mathrm{a}}$ & 2.2 & 0.001 \\
Actual administration, $\mathrm{kg} / \mathrm{d}$ & & & & & & \\
Flax oil & 0.40 & 0.40 & 0.40 & 0.39 & 0.01 & 0.93 \\
Flax hulls, DM basis & 1.80 & 1.76 & 1.68 & 1.68 & 0.04 & 0.07 \\
Oil from flax hulls & 0.54 & 0.52 & 0.50 & 0.50 & 0.01 & 0.07 \\
Total oil supplied & 0.94 & 0.92 & 0.90 & 0.89 & 0.02 & 0.12 \\
\hline
\end{tabular}

${ }^{\mathrm{a}-\mathrm{c}}$ Means within a row with different superscripts differ at $P \leq 0.05(\mathrm{n}=4)$.

${ }^{1} \mathrm{ABO} / \mathrm{ABO}=$ oil and hulls infused in the abomasum; $\mathrm{RUM} / \mathrm{ABO}=$ oil administrated in the rumen and hulls infused in the abomasum; RUM/RUM = oil and hulls administered in the rumen and abomasal infusion of water; $\mathrm{ABO} / \mathrm{RUM}=$ oil infused in the abomasum and hulls administered in the rumen.

${ }^{2}$ Intake of the basal ration only, not including amounts of flax hulls and flax oil administered.

${ }^{3}$ Intake of the basal ration plus amounts of flax hulls and flax oil administered.

between cows fed $3 \%$ flax oil in the diet and those fed a diet with no added fat. Moreover, Benchaar et al. (2008) reported no difference in total tract digestibility of DM, CP, and ADF between dairy cows fed 0, 2, 3, and $4 \%$ flax oil in a diet based on a mixture of $24 \%$ grass silage and $24 \%$ corn silage, which is similar to the type of forages used in the present experiment. Greater concentrations of flax oil in the DM were administered in the present experiment than in the experiments of Ueda et al. (2003) and Benchaar et al. (2008), which may explain discrepancies between experiments. Doreau et al. (2009) also suggested that the level of flax FA supply is the main factor responsible for differences in digestibility between experiments.

Digestibility of $\mathrm{CP}$ was similar for $\mathrm{ABO} / \mathrm{ABO}$ and RUM/ABO treatments (72.6 vs. $70.0 \%$ ) and for RUM/ RUM and ABO/RUM treatments (73.6 vs. $73.5 \%$ ). These results may indicate that unprotected flax oil has no effect on CP digestibility, which agrees with the results of Sutton et al. (1983) for sheep fed unprotected and protected flax oil at $6.7 \%$ of the DM. Cows administered with flax hulls in the rumen showed higher $\mathrm{CP}$ apparent digestibility than those on the RUM/ABO treatment, which may result in increased $\mathrm{CP}$ digestibility of hulls by ruminal microorganisms and enhanced overall digestion in the gastrointestinal tract.

Apparent digestibility of ether extract was higher when flax hulls were administered in the rumen (RUM/ RUM and ABO/RUM) compared with treatments where flax hulls were infused in the abomasum $(\mathrm{ABO} / \mathrm{ABO}$ and RUM/ABO). Flax hulls $(1.8 \mathrm{~kg} / \mathrm{d})$ were suspended in $18.2 \mathrm{~kg}$ of tap water for the abomasal infusion, which might have increased the flow rate of digesta in the intestine because of the large amount of water being infused in the abomasum and lowered the apparent digestibility of lipids because of inefficient hydrolysis and absorption of FA by the intestinal mucosa cells.

The lowest digestibility of ADF and NDF was obtained when both flax products were added in the rumen. With high forage diets, higher total tract digestibility of ADF and NDF with 3\% flax oil supplementation in the diet of lactating dairy cows has been shown to result in increased ruminal digestibility of these fractions (Ueda et al., 2003). High amounts of fat in the rumen for cows on the RUM/RUM treatment may have been detrimental for fiber degradation because of a layer of lipid that coats the feed particles and because of cytotoxic effects of unsaturated FA on membrane function of eukaryotic cells (Jenkins, 1993). Moreover, cows fed supplemental flax oil have considerably lower numbers of cellulolytic bacteria than those fed no added fat (Yang et al., 2009), probably because of toxic effects of high amounts of unsaturated FA in the rumen, which likely accounted for the lower ruminal digestibility of NDF and ADF for cows on the RUM/RUM treatment. However, when only 1 flax product was administered in the rumen (RUM/ $\mathrm{ABO}$ and $\mathrm{ABO} / \mathrm{RUM})$, this resulted in a lower amount of fat delivered in the rumen $(2.3$ and $3.2 \%$ of total DM input, respectively) than when both were administered together in the rumen (RUM/RUM; $5.8 \%$ of total DM 
Table 3. Milk production and composition of Holstein cows administered with flax hulls and flax oil in the rumen, or infused in the abomasum, or both

\begin{tabular}{lcccccc}
\hline & \multicolumn{5}{c}{ Treatment $^{1}$} & \\
\cline { 2 - 5 } Item & ABO/ABO & RUM/ABO & RUM/RUM & ABO/RUM & SE & $P$-value \\
\hline Milk production, kg/d & $27.4^{\mathrm{ab}}$ & $29.1^{\mathrm{a}}$ & $26.2^{\mathrm{b}}$ & $27.1^{\mathrm{b}}$ & 1.79 & 0.01 \\
4\% FCM, kg/d & $24.6^{\mathrm{a}}$ & $25.0^{\mathrm{a}}$ & $20.4^{\mathrm{b}}$ & $24.8^{\mathrm{a}}$ & 1.57 & 0.02 \\
Milk composition, $\%$ & & & & & & \\
Protein & 3.79 & 3.42 & 3.42 & 3.48 & 0.10 & 0.07 \\
Fat & 3.56 & 2.56 & 2.56 & 3.02 & 0.36 & 0.22 \\
TS & 13.1 & 11.7 & 11.7 & 12.3 & 0.44 & 0.16 \\
Lactose & 4.77 & 4.73 & 4.73 & 4.79 & 0.05 & 0.72 \\
Urea N, mg/dL & $14.8^{\mathrm{a}}$ & $10.2^{\mathrm{b}}$ & $10.2^{\mathrm{b}}$ & $12.8^{\mathrm{a}}$ & 1.76 & 0.001 \\
Milk yield, kg/d & & & & & & \\
Protein & $0.97^{\mathrm{a}}$ & $0.95^{\mathrm{ab}}$ & $0.86^{\mathrm{b}}$ & $0.88^{\mathrm{ab}}$ & 0.05 & 0.03 \\
Fat & 0.95 & 0.76 & 0.64 & 0.93 & 0.09 & 0.22 \\
TS & 3.56 & 3.42 & 3.03 & 3.31 & 0.22 & 0.12 \\
Lactose & $1.31^{\mathrm{ab}}$ & $1.38^{\mathrm{a}}$ & $1.24^{\mathrm{b}}$ & $1.30^{\mathrm{ab}}$ & 0.10 & 0.05 \\
SCS, $\log _{10} \mathrm{SCC}$ & 1.21 & 1.38 & 1.38 & 1.17 & 0.48 & 0.88 \\
\hline
\end{tabular}

a,b Means within a row with different superscripts differ at $P \leq 0.05(\mathrm{n}=4)$.

${ }^{1} \mathrm{ABO} / \mathrm{ABO}=$ oil and hulls infused in the abomasum; $\mathrm{RUM} / \mathrm{ABO}=$ oil administrated in the rumen and hulls infused in the abomasum; RUM/RUM = oil and hulls administered in the rumen and abomasal infusion of water; $\mathrm{ABO} / \mathrm{RUM}=$ oil infused in the abomasum and hulls administered in the rumen.

input). Thus, total tract digestibility of ADF and NDF may be less affected when flax oil is administered in the abomasum because increased postruminal digestion of fiber may compensate to a considerable extent for the severe depression in rumen digestion caused by the oils (Sutton et al., 1983). In a study where 4 doses of flax oil were fed to sheep $(0,2.0,3.9$, and $6.0 \%$ of the DM), Ikwuegbu and Sutton (1982) reported that the major oil effect was to shift the site of ADF digestion from the rumen to the intestine, resulting in a small reduction of total tract digestibility of $\mathrm{ADF}$ for the 3 low oil doses but not for the $6.0 \%$ level. The same effect was observed in the present experiment in that the only treatment with ruminal flax oil concentration higher than $6.0 \%$ was RUM/RUM, and this was the only treatment that caused a reduction of total tract digestibility of $\mathrm{ADF}$.

\section{Milk Production and Composition}

The site of oil administration had no effect on milk production (27.4 and $29.1 \mathrm{~kg} / \mathrm{d}$ for $\mathrm{ABO} / \mathrm{ABO}$ and RUM/ABO, respectively) when cows were infused with hulls in the abomasum (Table 3). Similarly, when cows received hulls in the rumen, infusion of oil in the rumen and the abomasum resulted in similar milk production $(26.2$ and $27.1 \mathrm{~kg} / \mathrm{d})$. The lack of effect of flax oil supplementation on milk yield has previously been reported at $5.2 \%$ incorporation of the dietary DM for cows fed a high forage diet (Roy et al., 2006) and for cows fed 2.2 and $4.4 \%$ flax oil (Dhiman et al., 2000). On the other hand, a linear increase in milk production has been reported for cows fed $0,2,3$, and $4 \%$ flax oil in the DM (Benchaar et al., 2008) and higher milk yield for cows supplemented with $4 \%$ flax oil in the DM compared with those fed a no-fat diet (Bu et al., 2007). However, milk production was lower for cows on the RUM/RUM and ABO/RUM treatments than for those on the RUM/ABO treatment, suggesting that the presence of flax hulls in the rumen and, thus, the lower total DM input (Table 3) was responsible for the decrease in milk production.

No difference was found in yield of $4 \% \mathrm{FCM}$ among the $\mathrm{ABO} / \mathrm{ABO}, \mathrm{RUM} / \mathrm{ABO}$, and $\mathrm{ABO} / \mathrm{RUM}$ treatments. The lowest yield of $4 \% \mathrm{FCM}$ was obtained for cows on the RUM/RUM treatment, which was probably caused by the lower DMI and the lower digestibility of fiber attributable to the high amount of oil present in the rumen $(7.8 \%)$. Similar results have been previously reported by Martin et al. (2008) for cows supplemented with $5.8 \%$ flax oil.

Milk concentrations of fat, TS, and lactose were similar among treatments as previously reported by $\mathrm{Bu}$ et al. (2007) for cows supplemented with $4 \%$ flax oil and those fed a diet with no added fat. Milk protein concentration tended $(P=0.07)$ to be higher for cows on the $\mathrm{ABO} / \mathrm{ABO}$ treatment compared with cows on the other treatments. Fat supplementation decreased milk protein concentration in some cases (Grummer, 1988) but not in others (Dhiman et al., 2000). Numerical values of milk fat concentration decreased with a greater supply of 18:3 in the rumen as shown for cows on the RUM/ABO and RUM/RUM treatments compared with those on the $\mathrm{ABO} / \mathrm{ABO}$ treatment. Dhiman et al. (2000) reported that $4.4 \%$ flax oil supplementation decreased milk fat percentage, although $\mathrm{Bu}$ et al. 
(2007) found that 4\% flax oil addition to the DM had no effect. According to Shingfield and Griinari (2007), milk fat depression is associated with the source and not the amount of polyunsaturated FA supplemented in the diet of dairy cows.

Milk concentration of urea $\mathrm{N}$ was lower when flax oil was administered in the rumen compared with when it was infused in the abomasum. This may suggest that flax oil in the rumen could affect microbial protein synthesis in the rumen, which would decrease ammonia $\mathrm{N}$ concentration in the rumen and urea $\mathrm{N}$ in milk. The effects of feeding protected and unprotected fat supplements on milk urea N (DePeters and Cant, 1992) and ruminal ammonia $\mathrm{N}$ concentrations are still unclear (Yang et al., 2009).

Yield of milk protein was lower for cows on the RUM/ RUM treatment than for those on the $\mathrm{ABO} / \mathrm{ABO}$ treatment and no difference was found between cows on the $\mathrm{ABO} / \mathrm{ABO}$ treatment and those on the RUM/ $\mathrm{ABO}$ and $\mathrm{ABO} / \mathrm{RUM}$ treatments (Table 3). Yields of milk fat and TS were similar among treatments. Yield of milk lactose was higher on the RUM/ABO treatment than on the RUM/RUM treatment and no difference was found between cows on the $\mathrm{ABO} / \mathrm{ABO}, \mathrm{ABO} /$ RUM, and RUM/RUM treatments. Differences in milk yield components reflected mainly differences in milk production and milk composition.

\section{Milk FA Composition}

Proportions of 4:0, 5:0, 7:0, 9:0, 11:0, cis-11 12:1, trans-10, cis-12 18:2, 20:0, 22:0, cis-8, cis-11, cis-14 20:3, cis-5, cis-8, cis-11, cis-14 20:4, and cis-7, cis-10, cis-13, cis-16, cis-19 22:5 in milk fat were not affected by treatments (Table 4). Cows on the RUM/RUM treatment had the lowest proportions of 6:0, 8:0, and 10:0 compared with those on the other 3 treatments (Table 4), which agrees with the decrease in proportion of 10:0 in milk fat of cows supplemented with $4 \%$ flax oil compared with those fed a diet with no added fat (Bu et al., 2007). The lowest proportion of 16:0 in milk fat was obtained for cows on the ABO/RUM treatment, and no difference was found between cows on the $\mathrm{ABO} / \mathrm{ABO}$ and $\mathrm{RUM} / \mathrm{ABO}$ treatments and between those on the RUM/ABO and RUM/RUM treatments. Cows supplemented with oil in the rumen (RUM/RUM and RUM/ABO) presented higher trans-9 16:1 proportions in milk fat than those infused with oil in the abomasum $(\mathrm{ABO} / \mathrm{ABO}$ and $\mathrm{ABO} / \mathrm{RUM})$, which agrees with the greater duodenal flow of trans-9 16:1 in cows supplemented with $3 \%$ flax oil compared with those without fat supplementation (Loor et al., 2004).

Administration of oil and hulls in the rumen (RUM/ RUM) resulted in the highest proportions of some mi- nor intermediate products of biohydrogenation (trans -9 18:1, trans-9, trans-12 18:2, and trans-13+14 18:1 + cis$6+8$ 18:1) and total trans FA in milk fat compared with the other treatments (Table 4). On the other hand, the lowest proportions of 18:0, cis-9 18:1, trans-13+14 18:1 + cis-6+8 18:1 and highest concentrations of cis-9, cis12 , cis-15 18:3 in milk fat were observed on the $\mathrm{ABO} /$ $\mathrm{ABO}$ treatment because of higher rumen bypass of flax oil. Because amounts of biohydrogenation intermediates produced in the rumen influence their concentrations in milk (Chilliard et al., 2000), results of the present experiment suggest that the more extensive biohydrogenation when oil was infused in the rumen versus the abomasum resulted in more extensive degradation of fat as shown by higher concentrations of trans-11 18:1 and total trans FA in milk fat on the RUM/RUM and RUM/ABO treatments than on the $\mathrm{ABO} / \mathrm{ABO}$ and $\mathrm{ABO} / \mathrm{RUM}$ treatments. When oil was infused in the rumen, the site of administration of flax hulls had no effect. Similarly, when oil was infused in the abomasum, the site of administration of flax hulls had no effect. These results suggest that trans FA content in milk fat was attributable mainly to ruminal biohydrogenation of FA from flax oil rather than from flax hulls.

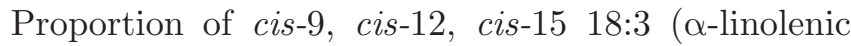
acid) was significantly increased when flax oil was infused in the abomasum (14.4 and $11.6 \%$ of total FA in milk for $\mathrm{ABO} / \mathrm{ABO}$ and $\mathrm{ABO} / \mathrm{RUM}$ treatments, respectively) compared with when it was administered in the rumen. Similarly, cis-9, cis-12, cis-15 18:3 proportion increased to $13.9 \%$ of total FA in milk fat with abomasal infusion of $500 \mathrm{~g}$ of flax oil/d (Petit et al., 2002). When cows were infused with oil in the rumen, administration of flax hulls in the abomasum (RUM/ ABO) led to higher cis-9, cis-12, cis-15 18:3 proportion in milk fat than when flax hulls were administrated in the rumen (RUM/RUM). This result may suggest that biohydrogenation of polyunsaturated FA in the rumen was higher on the RUM/RUM treatment than on the RUM/ABO treatment as indicated by higher proportions of some minor intermediate products of biohydrogenation (trans-9 18:1, trans-9, trans-12 18:2, and trans-13+14 18:1 + cis-6+8 18:1) in milk fat of cows on the RUM/RUM treatment.

Concentrations of SCFA in milk fat were reduced when both flax products were added in the rumen (RUM/RUM) compared with the other treatments (Table 4). This result would agree with the decrease in fiber digestibility and acetate to propionate ratio in the rumen (Gagnon et al., 2009) because of the high fat concentration in the rumen for cows on the RUM/RUM treatment, which likely negatively affected de novo synthesis of SCFA in the mammary gland. 
Table 4. Milk fatty acid profile of Holstein cows administered with flax hulls and flax oil in the rumen, or infused in the abomasum, or both

\begin{tabular}{|c|c|c|c|c|c|c|}
\hline \multirow{2}{*}{$\begin{array}{l}\text { Fatty acid, } \\
\% \text { of total fatty acid }\end{array}$} & \multicolumn{4}{|c|}{ Treatment $^{1}$} & \multirow[b]{2}{*}{$\mathrm{SE}^{2}$} & \multirow[b]{2}{*}{$P$-value } \\
\hline & $\mathrm{ABO} / \mathrm{ABO}$ & RUM/ABO & RUM/RUM & $\mathrm{ABO} / \mathrm{RUM}$ & & \\
\hline $4: 0$ & 4.64 & 5.51 & 4.13 & 5.21 & 0.40 & 0.17 \\
\hline $5: 0$ & 0.04 & 0.05 & 0.05 & 0.06 & 0.01 & 0.90 \\
\hline $6: 0$ & $2.42^{\mathrm{a}}$ & $2.31^{\mathrm{a}}$ & $1.58^{\mathrm{b}}$ & $2.33^{\mathrm{a}}$ & 0.17 & 0.002 \\
\hline $7: 0$ & 0.08 & 0.10 & 0.08 & 0.10 & 0.01 & 0.56 \\
\hline $8: 0$ & $1.46^{\mathrm{a}}$ & $1.26^{\mathrm{b}}$ & $0.91^{\mathrm{c}}$ & $1.27^{\mathrm{b}}$ & 0.09 & 0.001 \\
\hline 9:0 & 0.11 & 0.11 & 0.09 & 0.09 & 0.02 & 0.49 \\
\hline $10: 0$ & $3.43^{\mathrm{a}}$ & $2.57^{\mathrm{b}}$ & $1.73^{\mathrm{c}}$ & $2.56^{\mathrm{b}}$ & 0.21 & 0.0003 \\
\hline 11:0 & 0.13 & 0.11 & 0.14 & 0.10 & 0.01 & 0.27 \\
\hline $12: 0$ & $3.81^{\mathrm{a}}$ & $2.90^{\mathrm{b}}$ & $2.29^{\mathrm{c}}$ & $2.63^{\mathrm{bc}}$ & 0.21 & 0.0007 \\
\hline cis-11 12:1 & 0.18 & 0.18 & 0.20 & 0.12 & 0.03 & 0.22 \\
\hline $13: 0$ & $0.14^{\mathrm{ab}}$ & $0.14^{\mathrm{ab}}$ & $0.16^{\mathrm{a}}$ & $0.11^{\mathrm{b}}$ & 0.01 & 0.03 \\
\hline 14:0 & $9.32^{\mathrm{a}}$ & $9.36^{\mathrm{a}}$ & $8.46^{\mathrm{b}}$ & $7.67^{\mathrm{c}}$ & 0.22 & $<0.0001$ \\
\hline cis-9 14:1 & $0.58^{\mathrm{bc}}$ & $0.72^{\mathrm{b}}$ & $1.04^{\mathrm{a}}$ & $0.44^{\mathrm{c}}$ & 0.07 & 0.0006 \\
\hline $15: 0$ & $0.84^{\mathrm{ab}}$ & $0.90^{\mathrm{a}}$ & $0.96^{\mathrm{a}}$ & $0.70^{\mathrm{b}}$ & 0.05 & 0.01 \\
\hline $16: 0$ & $20.1^{\mathrm{a}}$ & $19.2^{\mathrm{ab}}$ & $18.7^{\mathrm{b}}$ & $16.1^{\mathrm{c}}$ & 0.47 & 0.0001 \\
\hline trans-9 16:1 & $0.07^{\mathrm{b}}$ & $0.16^{\mathrm{a}}$ & $0.19^{\mathrm{a}}$ & $0.08^{\mathrm{b}}$ & 0.01 & 0.0006 \\
\hline cis-9 16:1 & $1.11^{\mathrm{bc}}$ & $1.36^{\mathrm{ab}}$ & $1.79^{\mathrm{a}}$ & $0.89^{c}$ & 0.12 & 0.003 \\
\hline $17: 0$ & $0.52^{\mathrm{bc}}$ & $0.59^{\mathrm{a}}$ & $0.56^{\mathrm{ab}}$ & $0.45^{\mathrm{c}}$ & 0.02 & 0.005 \\
\hline 18:0 & $8.54^{\mathrm{b}}$ & $12.8^{\mathrm{a}}$ & $11.6^{\mathrm{a}}$ & $14.1^{\mathrm{a}}$ & 0.77 & 0.005 \\
\hline trans-9 18:1 & $0.19^{\mathrm{c}}$ & $0.42^{\mathrm{b}}$ & $0.71^{\mathrm{a}}$ & $0.29^{\mathrm{bc}}$ & 0.04 & 0.0002 \\
\hline trans-11 18:1 & $0.89^{\mathrm{b}}$ & $2.71^{\mathrm{a}}$ & $2.88^{\mathrm{a}}$ & $1.29^{\mathrm{b}}$ & 0.17 & $<0.0001$ \\
\hline trans $-13+1418: 1+$ cis- $6+818: 1$ & $0.36^{\mathrm{c}}$ & $2.06^{\mathrm{b}}$ & $4.38^{\mathrm{a}}$ & $1.61^{\mathrm{b}}$ & 0.35 & 0.0006 \\
\hline cis-9 18:1 & $17.3^{\mathrm{c}}$ & $21.8^{\mathrm{b}}$ & $26.5^{\mathrm{a}}$ & $21.7^{\mathrm{b}}$ & 1.19 & $<0.0001$ \\
\hline cis-11 18:1 & $0.63^{\mathrm{b}}$ & $0.76^{\mathrm{ab}}$ & $0.87^{\mathrm{a}}$ & $0.70^{\mathrm{ab}}$ & 0.06 & 0.04 \\
\hline 19:0 & $0.17^{\mathrm{c}}$ & $0.74^{\mathrm{b}}$ & $1.78^{\mathrm{a}}$ & $0.59^{\mathrm{bc}}$ & 0.09 & $<0.0001$ \\
\hline trans -9, trans-12 18:2 & $0.10^{\mathrm{bc}}$ & $0.15^{\mathrm{b}}$ & $0.25^{\mathrm{a}}$ & $0.07^{\mathrm{c}}$ & 0.02 & 0.001 \\
\hline cis-9, cis-12 18:2 & $6.14^{\mathrm{a}}$ & $3.31^{\mathrm{c}}$ & $2.52^{\mathrm{d}}$ & $5.03^{\mathrm{b}}$ & 0.22 & $<0.0001$ \\
\hline $20: 0$ & 0.29 & 0.36 & 0.35 & 0.28 & 0.03 & 0.14 \\
\hline cis-8 20:1 & $0.19^{\mathrm{b}}$ & $0.23^{\mathrm{ab}}$ & $0.28^{\mathrm{a}}$ & $0.18^{\mathrm{b}}$ & 0.02 & 0.02 \\
\hline cis-11 20:1 & 0.16 & 0.17 & 0.20 & 0.15 & 0.02 & 0.09 \\
\hline cis-9, cis-12, cis-15 18:3 & $14.4^{\mathrm{a}}$ & $4.78^{\mathrm{b}}$ & $2.33^{\mathrm{c}}$ & $11.6^{\mathrm{a}}$ & 0.59 & $<0.0001$ \\
\hline cis-9, trans-11 18:2 & $0.38^{\mathrm{c}}$ & $1.12^{\mathrm{ab}}$ & $1.66^{\mathrm{a}}$ & $0.53^{\mathrm{bc}}$ & 0.18 & 0.002 \\
\hline trans-10, cis-12 18:2 & 0.01 & 0.02 & 0.02 & 0.01 & 0.01 & 0.32 \\
\hline cis-11, cis-14 20:2 & $0.14^{\mathrm{a}}$ & $0.14^{\mathrm{a}}$ & $0.03^{\mathrm{b}}$ & $0.12^{\mathrm{a}}$ & 0.02 & 0.01 \\
\hline cis-11, cis-14, cis-17 20:3 & $0.24^{\mathrm{a}}$ & $0.17^{\mathrm{a}}$ & $0.07^{\mathrm{b}}$ & $0.20^{\mathrm{a}}$ & 0.02 & 0.006 \\
\hline $22: 0$ & 0.18 & 0.18 & 0.14 & 0.11 & 0.04 & 0.46 \\
\hline cis-8, cis-11, cis-14 20:3 & 0.10 & 0.10 & 0.07 & 0.08 & 0.02 & 0.22 \\
\hline cis-5, cis-8, cis-11, cis-14 20:4 & 0.15 & 0.13 & 0.11 & 0.13 & 0.01 & 0.92 \\
\hline cis-5, cis-8, cis-11, cis-14, cis-17 20:5 & $0.22^{\mathrm{a}}$ & $0.14^{\mathrm{b}}$ & $0.09^{\mathrm{b}}$ & $0.16^{\mathrm{ab}}$ & 0.03 & 0.006 \\
\hline cis-7, cis-10, cis-13, cis-16, cis-19 22:5 & 0.22 & 0.22 & 0.12 & 0.18 & 0.04 & 0.10 \\
\hline Total trans ${ }^{3}$ & $1.19^{\mathrm{b}}$ & $3.59^{\mathrm{a}}$ & $4.06^{\mathrm{a}}$ & $1.74^{\mathrm{b}}$ & 0.20 & 0.0001 \\
\hline$n-3^{4}$ & $15.1^{\mathrm{a}}$ & $5.3^{\mathrm{b}}$ & $2.62^{\mathrm{c}}$ & $12.2^{\mathrm{a}}$ & 0.61 & $<0.0001$ \\
\hline$n-6^{5}$ & $6.53^{\mathrm{a}}$ & $3.7^{\mathrm{c}}$ & $2.73^{\mathrm{d}}$ & $5.36^{\mathrm{b}}$ & 0.22 & $<0.0001$ \\
\hline$n-6: n-3$ & $0.43^{\mathrm{b}}$ & $0.69^{\mathrm{b}}$ & $1.04^{\mathrm{a}}$ & $0.44^{\mathrm{b}}$ & 0.06 & 0.0004 \\
\hline
\end{tabular}

${ }^{\mathrm{a}-\mathrm{d}}$ Means within a row with different superscripts differ at $P<0.05(\mathrm{n}=4)$.

${ }^{1} \mathrm{ABO} / \mathrm{ABO}=$ oil and hulls infused in the abomasum; $\mathrm{RUM} / \mathrm{ABO}=$ oil administrated in the rumen and hulls infused in the abomasum; RUM/RUM = oil and hulls administered in the rumen and abomasal infusion of water; $\mathrm{ABO} / \mathrm{RUM}=$ oil infused in the abomasum and hulls administered in the rumen.

${ }^{2}$ Least squares means with pooled SE.

${ }^{3}$ Sum of trans-9 16:1, trans-9 18:1, trans-11 18:1, and trans-12 18:2.

${ }^{4}$ Sum of cis-9, cis-12, cis-15 18:3; cis-11, cis-14, cis-17 20:3; cis-5, cis-8, cis-11, cis-14, cis-17 20:5; and cis-7, cis-10, cis-13, cis-16, cis-19 22:5.

${ }^{5}$ Sum of cis-9, cis-12 18:2; cis-11, cis-14 20:2; cis-8, cis-11, cis-14 20:3; and cis-5, cis-8, cis-11, cis-14 20:4.

Proportions of n-3 and n-6 FA in milk fat were higher on the $\mathrm{ABO} / \mathrm{ABO}$ and $\mathrm{ABO} / \mathrm{RUM}$ treatments than on the RUM/RUM and RUM/ABO treatments, thus demonstrating that rumen bypass of flax oil and not that of flax hulls is the main factor responsible for enhancing these FA in milk fat of cows fed flax products. However, rumen bypass of hulls with infusion of oil in the rumen contributed significantly to increase proportions of n-3 FA in milk fat as shown by enhanced concentrations of these FA for cows on the RUM/ABO 
treatment compared with those on the RUM/RUM treatment (Table 4). Although the lowest proportion of cis-9, cis-12, cis-15 18:3 was obtained for cows on the RUM/RUM treatment, the proportion $(2.33 \%$ of total FA) reached with administration of flax oil and hulls in the rumen was much higher than the 1.06, 0.91, and $1.56 \%$ average values obtained for unprotected seed, oil, and protected seed from flax, respectively (Glasser et al., 2008). Although the cows on the RUM/RUM treatment had a higher n- 6 to n-3 FA ratio in milk fat, all ratios were lower than the 4 to 1 ratio ideal to reduce the potential risk of coronary heart diseases and improve human health (Sim, 1998).

\section{CONCLUSIONS}

The site of infusion of flax oil and hulls had an important effect on proportions of FA in milk fat and digestibility in dairy cows. Greater amounts of lipids in the rumen decreased dry matter intake, fiber digestibility, and milk production. When oil was infused in the rumen, the site of administration of flax hulls had no effect on milk FA profile. Similarly, when oil was infused in the abomasum, the site of administration of flax hulls had no effect. These results suggest that trans FA content of milk fat was attributable mainly to ruminal biohydrogenation of FA from flax oil rather than from flax hulls. All ratios of n- 6 to n- 3 FA in milk fat were lower than the 4 to 1 ratio, which is ideal to enhance consumer's health.

\section{ACKNOWLEDGMENTS}

C.C. was a recipient of a fellowship from the National Science and Engineering Research Council of Canada (Ottawa, ON, Canada). D.D.S.K. and R. K. were recipients of a scholarship and G.T.D.S. and L.M.Z. were recipients of a fellowship from Conselho Nacional de Desenvolvimento Científico e Tecnológico and Fundação Araucária do Paraná (Brasilia, Brazil). The present study was funded by Agriculture and Agri-Food Canada (Sherbrooke, QC, Canada). The authors express their gratitude to the staff of the Dairy and Swine Research and Development Centre (Sherbrooke, QC, Canada) for their contribution to the present study. We especially thank Véronique Roy and Liette Veilleux for technical assistance and Steve Méthot (Agriculture and Agri-Food Canada, Sherbrooke, QC, Canada) for his help in the statistical analyses.

\section{REFERENCES}

Allen, M. S. 2000. Effects of diet on short-term regulation of feed intake by lactating dairy cattle. J. Dairy Sci. 83:1598-1624.

AOAC. 1990. Official Methods of Analysis. 15th ed. AOAC, Washington, DC.
Benchaar, C., M. Eugène, C. Côrtes, A. V. Chaves, H. V. Petit, T. A. McAllister, A. D. Iwaasa, and P. Y. Chouinard. 2008. Digestion, milk production, and milk composition of dairy cows fed increasing amounts of linseed oil. J. Dairy Sci. 91(E-Suppl. 1):72.

Benson, J. A., C. K. Reynolds, D. J. Humphries, S. M. Rutter, and D. E. Beever. 2001. Effects of abomasal infusion of long-chain fatty acids on intake, feeding behavior and milk production in dairy cows. J. Dairy Sci. 84:1182-1191.

Bu, D. P., J. Q. Wang, T. R. Dhiman, and S. J. Liu. 2007. Effectiveness of oils rich in linoleic and linolenic acids to enhance conjugated linoleic acid in milk from dairy cows. J. Dairy Sci. 90:998-1007.

CCAC. 1993. Guide to Care and Use of Experimental Animals. Vol. 1. E. D. Offert, B. M. Cross, and A. A. McWilliam, ed. Canadian Council on Animal Care, Ottawa, Ontario, Canada.

Chilliard, Y., A. Ferlay, R. Mansbridge, and M. Doreau. 2000. Ruminant milk fat plasticity: Nutritional control of saturated, polyunsaturated, trans and conjugated fatty acids. Ann. Zootech. 49:181-205.

Chouinard, P. Y., V. Girard, and G. J. Brisson. 1997. Performance and profiles of milk fatty acids of cows fed full-fat, heat-treated soybeans using various processing methods. J. Dairy Sci. 80:334342.

DePeters, E. J., and J. P. Cant. 1992. Nutritional factors influencing the nitrogen composition of bovine milk: A review. J. Dairy Sci. $75: 2043-2070$.

Dhiman, T. R., L. D. Satter, M. W. Pariza, M. P. Galli, K. Albridht, and M. X. Tolosa. 2000. Conjugated linoleic acid (CLA) content of milk from cows offered diets rich in linoleic and linolenic acid. J. Dairy Sci. 83:1016-1027.

Doreau, M., E. Aurousseau, and C. Martin. 2009. Effects of linseed lipids fed as rolled seeds, extruded seeds or oil on organic matter and crude protein digestion in cows. Anim. Feed Sci. Technol. 150:187-196.

Drackley, J. K., T. R. Overton, G. Ortiz-Gonzalez, A. D. Beaulieu, D. M. Barbano, J. M. Lynch, and E. G. Perkins. 2007. Responses to increasing amounts of high-oleic sunflower fatty acids infused into the abomasum of lactating dairy cows. J. Dairy Sci. 90:51655175 .

Edmonson, A. J., I. J. Lean, L. D. Weaver, T. Farver, and G. Webster. 1989. A body condition scoring chart for Holstein for dairy cows. J. Dairy Sci. 72:68-78.

Forbes, J. M. 2000. Physiological and metabolic aspects of feed intake control. Pages 319-333 in Part III: Intake and Utilization. Farm Animal Metabolism and Nutrition: Critical reviews. Vol. 1. J. P. F. D'Mello, ed. CABI Publishing, London, UK.

Fuentes, M. C., S. Calsamiglia, P. W. Cardozo, and B. Vlaeminck. 2009. Effect of $\mathrm{pH}$ and level of concentrate in the diet on the production of biohydrogenation intermediates in a dual-flow continuous culture. J. Dairy Sci. 92:4456-4466.

Gagnon, N., C. Côrtes, D. da Silva, R. Kazama, G. dos Santos, L. Zeoula, C. Benchaar, and H. V. Petit. 2009. Ruminal metabolism of flaxseed (Linum usitatissimum) lignans to the mammalian lignan enterolactone and its concentration in ruminal fluid, plasma, urine, and milk of dairy cows. Br. J. Nutr. 102:1015-1023.

Glasser, F., A. Ferlay, and Y. Chilliard. 2008. Oilseed lipid supplements and fatty acid composition of cow milk: A meta-analysis. J. Dairy Sci. 91:4687-4703.

Grummer, R. R. 1988. Influence of prilled fat and calcium salt of palm oil fatty acids on ruminal fermentation and nutrient digestibility. J. Dairy Sci. 71:117-123.

Ikwuegbu, O. A., and J. D. Sutton. 1982. The effect of varying the amount of linseed oil supplementation on rumen metabolism in sheep. Br. J. Nutr. 48:365-375.

Jenkins, T. C. 1993. Lipid metabolism in the rumen. J. Dairy Sci. 76:3851-3863.

Loor, J. J., K. Ueda, A. Ferlay, Y. Chilliard, and M. Doreau. 2004. Biohydrogenation, duodenal flow, and intestinal digestibility of trans fatty acids and conjugated linoleic acids in response to dietary forage:concentrate ratio and linseed oil in dairy cows. J. Dairy Sci. 87:2472-2485. 
Martin, C., J. Rouel, J. P. Jouany, M. Doreau, and Y. Chilliard. 2008. Methane output and diet digestibility in response to feeding dairy cows crude linseed, extruded linseed, or linseed oil. J. Anim. Sci. $86: 2642-2650$.

Mustafa, A. F., P. Y. Chouinard, and D. A. Christensen. 2003. Effects of feeding micronised flaxseed on yield and composition of milk from Holstein cows. J. Sci. Food Agric. 83:920-926.

National Research Council. 2001. Nutrient Requirements of Dairy Cattle. 7th rev. ed. Nat. Acad. Press, Washington, DC.

Park, P. W., and R. E. Goins. 1994. In situ preparation of fatty acid methyl esters for analysis of fatty acid composition in foods. J. Food Sci. 59:1262-1266.

Petit, H. V. 2003. Digestion, milk production, milk composition, and blood composition of dairy cows fed formaldehyde treated flaxseed or sunflower seed. J. Dairy Sci. 86:2637-2646.

Petit, H. V., C. Côrtes, D. da Silva, R. Kazama, N. Gagnon, C. Benchaar, G. T. dos Santos, and L. M. Zeoula. 2009. The interaction of monensin and flaxseed hulls on ruminal and milk concentration of the mammalian lignan enterolactone in late-lactating dairy cows. J. Dairy Res. 76:475-482.

Petit, H. V., R. J. Dewhurst, N. D. Scollan, J. G. Proulx, M. Khalid, W. Haresign, H. Twagiramungu, and G. E. Mann. 2002. Milk production and composition, ovarian function, and prostaglandin secretion of dairy cows fed omega-3 fats. J. Dairy Sci. 85:889-899.

Roy, A., A. Ferlay, K. J. Shingfield, and Y. Chilliard. 2006. Examination of the persistency of milk fatty acid composition responses to plant oils in cows fed different basal diets, wit particular emphasis on trans- $\mathrm{C}_{18: 1}$ fatty acids and isomers of conjugated linoleic acid. Anim. Sci. 82:479-492.

SAS Institute. 2000. SAS/STAT User's Guide. Release 8.02. SAS Institute, Cary, NC.

Shingfield, K. J., and J. M. Griinari. 2007. Role of biohydrogenation intermediates in milk fat depression. Eur. J. Lipid Sci. Technol. 109:799-816.
Sim, J. S. 1998. Designer eggs and their nutritional and functional significance. World Rev. Nutr. Diet. 83:89-101.

Simopoulos, A. P. 1996. Omega-3-fatty acids and public health. Pages 5-28 in Proc. Flax Council of Canada Conf.: Flax-The Next Decade, Winnipeg, MB, Canada. Flax Council of Canada, Winnipeg, MB, Canada.

Steel, R. G. D., and J. J. Torrie. 1980. Principles and Procedures of Statistics: A Biometrical Approach. 2nd ed. McGraw-Hill Book Co., New York, NY.

Sutton, J. D., R. Knight, A. B. McAllan, and R. H. Smith. 1983. Digestion and synthesis in the rumen of sheep given diets supplemented with free and protected oils. Br. J. Nutr. 49:419-432.

Troegeler-Meynadier, A., M. C. Nicot, C. Bayourthe, R. Moncoulon, and F. Enjalbert. 2003. Effects of $\mathrm{pH}$ and concentrations of linoleic and linolenic acids on extent and intermediates of ruminal biohydrogenation in vitro. J. Dairy Sci. 86:4054-4063.

Ueda, K., A. Ferlay, J. Chabrot, J. J. Loor, Y. Chilliard, and M. Doreau. 2003. Effect of linseed oil supplementation on ruminal digestion in dairy cows fed dies with different forage:concentrate ratios. J. Dairy Sci. 86:3999-4007.

Van Soest, P. J., J. B. Robertson, and B. A. Lewis. 1991. Methods for dietary fiber, neutral detergent fiber, and nonstarch polysaccharides in relation to animal nutrition. J. Dairy Sci. 74:3583-3597.

Wright, T., B. McBride, and B. Holub. 1998. Docosahexaenoic acid enriched milk. World Rev. Nutr. Diet. 83:160-165.

Yang, S. L., D. P. Bu, J. Q. Wang, Z. Y. Hu, D. Li, H. Y. Wei, L. Y. Zhou, and J. J. Loor. 2009. Soybean oil and linseed oil supplementation affect profiles of ruminal microorganisms in dairy cows. Animal 3:1562-1569. 